\title{
Let the Writer Beware! - a Look at Aspects of the EU Legislation Concerning Instructional Texts - By: PETER KASTBERG
}

Posted by Lene Lund on December 012008 21:11:29

\section{Let the Writer Beware!}

- a Look at Aspects of the EU Legislation Concerning Instructional Texts

We have probably all heard the story of the person who supposedly put a wet dog into the microwave oven to let it dry or the story of the person who drank coffee from a plastic cup and got severely burned, or the one in which a jogger stumbles and falls in the too long shoe laces of his / her sneakers. Whether or not stories like these are urban legends is hard to determine with any certainty. But judging from the ever increasing volume of the instruction manuals accompanying, for instance, our household appliances and other end user products there could be some truth to them.

\section{The heart of the matter}

Be they urban legends or real stories, what it all boils down to for the professional communicator is the fact that when we instruct somebody by means of an instructional text, chances are that that somebody will follow our instructions. And if our instructions are either not accurate or not understood, that same somebody could get hurt. This is an aspect of the professional communicator's / writer's / translator's life, as it were, which we cannot allow ourselves to take lightly.

\section{Disclaimer}

Keeping in tune with the overall topic of this essay, let me put forward a disclaimer at this point: This essay is not exhaustive, i.e. it cannot (and does not suppose to) give you complete information on the legal issues you may or may not face in the course of your professional life when writing for an EU audience. What we intend to do with this article is basically to raise your awareness. For your own sake as well as for the sake of your customers, clients, readers and listeners you should make yourself acquainted with the legal basics of your trade.

Needless to say, the legal basics which apply to you and your organization when you produce and distribute instructions are not necessarily European; EU law as discussed in this essay is merely one of many possible legal frameworks. The legal framework, which governs your instructions, is dependant upon where you and your 
organization do business.

\section{A Look at Euro-Lex - the Access to European Law}

But if we return to Europe, the web site "Eur-Lex" (please see Fact Box below) is quite helpful. On this web site I looked at different instances of European Union Law. One particular piece of legislation caught my attention since it - at a very basic but nevertheless crucial level - influences the production of instructions.

According Article 6 of the Council Directive 85/374/EEC of 25 July 1985 (for accurate information please visit: http://europa.eu/scadplus/leg/en/lvb//32012.htm) on "Defective products: liability" "[a] product is defective when it does not provide the safety which a person is entitled to expect, taking all circumstances into account, including [...] (a) the presentation of the product $[\ldots] "$.

Based on this Article 6 it becomes clear that the "presentation of the product", e.g. the end user instruction, is in fact an integral part of the product. This means, among other things, that liability issues may arise if the text accompanying a product "[...] does not provide the safety which a person is entitled to expect $[\ldots] "$.

\section{Let the Writer Beware!}

So what can you do to try and safeguard your readers and users? Well, the European Council Resolution of 17 December 1998, which explicitly deals with operating instructions for technical consumer goods (98/C 411/01) (Official Journal C 411, 31/12/1998 P. 0001 0004), is a good place to start. In the annex of that resolution you will find "Indications for Good operating Instructions for Technical Consumer Goods". These indications may be seen as a sort genre template, covering the essentials of the "good operating instruction".

However: Following the guidelines offered by the European Council will not free you from the responsibility of thinking for yourself when you communicate you next instruction ... 


\section{Author}

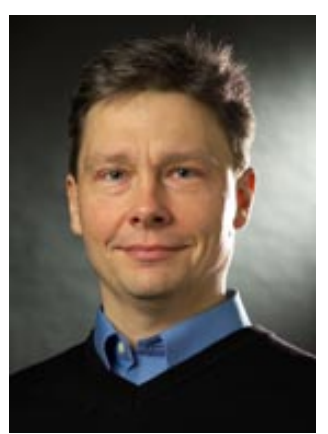

Peter Kastberg holds a Ph.D. in applied linguistics/technical communication, and is the Director of The ASB Research Group for Knowledge Communication, The Aarhus School of Business, Aarhus University, Denmark.

This article was uploaded to http://www.languageatwork.eu in July of 2009 and published under a "Creative Commons license Attribution Non-commercial (by-nc)" for more information please go to: http://creativecommons.org/about/license/ 